Économie

Économy

\title{
ÉTUDE DES PROJETS D'INVESTISSEMENT D'Atelier de production porcine. INCIDENCES DE CERTAINES VARIABLES STRATÉGIQUES
}

\author{
C. BRETTE \\ Institut national Paris-Grignon, Chaire de Zootechnie, \\ 16, Rue Claude-Bernard, \\ 75231 Paris Cedex 05
}

\section{RÉSUMÉ}

L'utilisation des critères de choix des investissements présente un grand intérêt pour analyser les conditions optimales de création de nouvelles unités de production porcine. Toutefois, la valeur de la décision dépend étroitement des hypothèses émises. Il est donc important de connaître a priori les facteurs susceptibles de modifier l'intérêt de l'investissement projeté. La démarche présentée est illustrée par l'étude d'un exemple d'atelier de production de porcelets.

L'analyse des incidences des composantes des variations des prix sur le bénéfice actualisé ou le taux de rentabilité, fait ressortir le rôle considérable de la tendance à long terme et le rôle négligeable des variations cycliques et saisonnières.

Le niveau de productivité des truies agit lourdement sur le résultat du bénéfice actualisé ou du taux de rentabilité.

Le coût du capital et la date de démarrage méritent également une attention particulière dans l'étude de tels projets.

\section{SUMMARY \\ INVESTMENT PROJECTS FOR PIG ENTERPRISES. \\ INCIDENCE OF SOME STRATEGIC VARIABLES}

Utilization of investment choice criteria is of great interest to analyse the optimum conditions for the creation of new pig production units. However, the value of the decision closely depends on the hypotheses considered. Thus, it is important to know, a priori, the factors liable 
to change the advantage of the investment planned. The present study is illustrated by an example taken from a piglet enterprise.

The analysis of the incidences of the price variation components on the actualized benefit or the efficiency rate clearly shows the considerable impact of the long-term tendency and the neglectable role of cyclic or seasonal variations.

The productivity level of the sows largely affects the result of the actualized benefit or the efficiency rate.

A special attention should also be payed to the capital cost and the starting date when studying such projects.

\title{
UN MODÈE DE PROJECTION DÉMOghaPHIQUE APPLIQUÉ AUX CHEPTELS ANIMAUX
}

\author{
L.-P. MAHÉ \\ Station d'Économie rurale, I. N. R. A., \\ École nationale supérieure agronomique, \\ 35042 Rennes
}

\section{RÉSUMÉ}

L'évolution dans le temps des cheptels animaux tant au niveau des élevages qu'au niveau global, est caractérisée par des fluctuations entraînant des déséquilibres importants. Or la dynamique des cheptels est le résultat des caractéristiques démographiques de l'espèce sous l'influence des décisions des éleveurs (variables de contrôle). Les méthodes de prévisions actuellement en cours utilisent soit une approche démographique partielle, soit une approche économique ne prenant pas en compte les lois démographiques. La présente recherche vise à intégrer l'ensemble des paramètres démographiques dans un seul modèle qui comporte en outre les variables de contrôle exprimant les décisions des éleveurs et leur comportement économique.

Le modèle démographique prend la forme d'un système d'équations aux différences finies et s'exprime par une relation matricielle : $\mathrm{X}_{t+1}=\mathrm{M}_{t} \mathrm{X}_{t}$ où $\mathrm{X}_{t}$ est le vecteur d'état du cheptel et $\mathrm{M}_{t}$ résume les caractéristiques démographiques du troupeau et comporte les variables de contrôle.

Les lois dynamiques d'un cheptel en reproduction sont étudiées à l'aide de ce modèle en paramétrant les variables de contrôle. Il existe des régimes permanents de croissance équilibrée (toutes les catégories d'animaux croissent exponentiellement à la même vitesse) et stationnaire (la composition et l'effectif du cheptel sont constants).

La relation entre les propriétés et les variables de contrôle est analysée.

\section{SUMMARY}

\section{MODEL, OF DEMOGRAPHIC FORECASTING APPLIED TO ANIMAL HERDS}

Both at the farm and at the aggregate level, herds undergo important fluctuations with time, which entail large disequilibria. The dynamics of a herds is the result of the demographic features of the species under the influence of the decisions of farmers (control variables). Forecasting me- 